\title{
YIELD OF COMMON FIG FERTIGATED WITH BOVINE BIOFERTILIZER IN THE SEMIARID REGION OF CEARÁ ${ }^{1}$
}

\author{
FRANCISCO LIMEIRA DA SILVA ${ }^{2}$, THALES VINICIUS DE ARAÚJO VIANA ${ }^{3}$, GEOCLEBER GOMES DE SOUSA ${ }^{4 *}$, SOLERNE CAMINHA \\ COSTA ${ }^{2}$, BENITO MOREIRA DE AZEVEDO ${ }^{3}$
}

\begin{abstract}
The objective was to evaluate the productivity of the fig tree the organic fertirrigation cattle under different environmental conditions in Ceará semiarid region. The experiment was conducted in the experimental area of the Teaching Unit, Research and Extension, the IFCE, North Lemon Tree, EC. The experimental design was a randomized complete block design with split plots, with four replications and three plants per plot. The plots consisted of three rooms (full sun - PS; trellis - LT and greenhouse - EST), the subplots, the concentrations of bovine biofertilizer diluted in water in the following concentrations: T0 $(0 \%$ of biofertilizer $+100 \%$ water); T1 (20\% biofertilizer $80+\%$ water $)$; T2 (40\% biofertilizer $+60 \%$ water $)$, T3 $(60 \%$ biofertiliante $+40 \%$ water) and subsubplot, the production cycles. The variables were evaluated: average fruit weight, fruit diameter, number of fruits per plant and yield. The cultivation environments (greenhouse and trellis) promote better performance on average mass and diameter of the fruit compared to plants grown in full sun during the production cycles of the fig crop grown in Ceará semiarid region. The bovine biofertilizer in the concentration of $60 \%$ promoted the highest mass, diameter, number of fruits per plant and the fig crop yield.
\end{abstract}

Keywords: Alternative feed, Energy values, Digestible amino acids.

\section{PRODUTIVIDADE DA FIGUEIRA CULTIVADA SOB FERTIRRIGAÇÃO COM BIOFERTILIZANTE BOVINO NO SEMIÁRIDO CEARENSE}

\begin{abstract}
RESUMO - Objetivou-se avaliar a produtividade da figueira fertirrigada com biofertilizante bovino sob diferentes ambientes de cultivo no semiárido cearense. O experimento foi conduzido na área experimental da Unidade de Ensino, Pesquisa e Extensão, do IFCE, Limoeiro do Norte, CE. O delineamento experimental foi em blocos completos ao acaso, com parcelas subsubdivididas, com quatro repetições e três plantas por parcela. As parcelas foram constituídas por três ambientes (pleno sol - PS; latada - LT e estufa - EST), as subparcelas, as concentrações do biofertilizante bovino diluídas em água nas seguintes concentrações: $\mathrm{T}_{0}(0 \%$ de biofertilizante $+100 \%$ de água); $\mathrm{T}_{1}(20 \%$ de biofertilizante $+80 \%$ de água $) ; \mathrm{T}_{2}(40 \%$ de biofertilizante $+60 \%$ de água) $; \mathrm{T}_{3}(60 \%$ de biofertiliante $+40 \%$ de água) e a subsubparcela, os ciclos produtivos. As variáveis avaliadas foram: massa média de frutos, diâmetro do fruto, número de frutos por planta e a produtividade. Os ambientes de cultivo (estufa e latada) promovem melhor desempenho em massa média e diâmetro do fruto comparadas aos das plantas cultivadas a pleno sol durante os ciclos produtivos da cultura da figueira cultivada no semiárido cearense. O biofertilizante bovino na concentração de $60 \%$ promoveu a maior massa, diâmetro, número de frutos por planta e produtividade da cultura da figueira.
\end{abstract}

Palavras-chave: Ficus carica L. Ambiente protegido. Fertilizante orgânico.

\footnotetext{
*Corresponding author

${ }^{1}$ Received for publication in $01 / 30 / 2015$; accepted in $01 / 22 / 2016$.

Paper extracted from the doctoral thesis of the first author.

${ }^{2}$ Agronomy Sector, Instituto Federal de Educação, Ciência e Tecnologia do Ceará, Umirim, CE, Brazil; fco_limeira@yahoo.com.br, solerne@ifce.edu.br.

${ }^{3}$ Department of Agricultural Engineering. Universidade Federal do Ceará, Fortaleza, CE, Brazil; thales@ufc.br, benitoazevedo@hotmail.com.

${ }^{4}$ Rural Development Institute, Universidade da Integração Internacional da Lusofonia Afro-Brasielira, Redenção, CE, Brazil; sousagg@unilab.edu.br.
} 


\section{INTRODUCTION}

The common fig (Ficus carica L.) is one of the oldest cultivated fruits in the world, and Brazil is the largest producer in the Southern Hemisphere, with cultivated area of approximately $3,020 \mathrm{ha}^{-1}$. In 2014 , Brazil produced $28,253 \mathrm{t}$ of figs from a total harvested area of 2,814 ha (average yield of 10,040 $\mathrm{kg} \mathrm{ha}{ }^{-1}$ ), which made Brazil one of the world's largest producers, and the main exporter, of fresh figs (IBGE, 2014).

Despite being considered a temperate crop, traditionally cultivated in the south and southeast regions of Brazil, the common fig has great capacity to adapt to different climatic conditions, being cultivated in cold and hot regions of the Northern Hemisphere (PIO et al., 2007).

The fig, like all plant species, demands a certain amount of nutrients in order to meet its nutritional requirements during the growing season. Instead of using synthetic inputs, organic inputs, including bovine biofertilizer, could be used to meet the crops nutritional requirements. Bovine biofertilizer could provide plants with a nonconcentrated, but adequate, source of macro and micronutrients (VIANA et al., 2013), and contribute to the release of humic substances into the soil (CAVALCANTE et al., 2007). This biofertilizer is a liquid organic fertilizer produced in aerobic or anaerobic medium using a mixture of organic material (manure) and water (SOUSA et al., 2013).

Silva et al. (2008) observed that fertilization with liquid bovine manure increased soil $\mathrm{pH}$, calcium, and magnesium. As a source of macro and micronutrients, bovine biofertilizer directly improves soil fertility, and indirectly increases soil $\mathrm{pH}$ and retention capacity, decreasing the loss of nutrients through leaching (LEONEL; DAMATTO JÚNIOR, 2008).

Organic inputs are often utilized in protected environments (i.e., greenhouses or covered structures). Protected environments preserve soil moisture and temperature, reducing the thermal amplitude and relative humidity, and this favors plant metabolism and the precocity of the vegetative cycle. In tropical regions, crop production can be difficult in environments where there is no control of temperature, humidity, or direct solar radiation (COSTA et al., 2011; SALES et al., 2014).

The recent adoption of protected environment techniques has made it possible to grow crops that were previously unviable under certain climatic conditions, and has solidified the use of greenhouses as a strategy for sustainable agricultural production (REIS et al., 2013).

This study evaluated the effect of cultivation environment and bovine fertilizer rate on fig yield in the semiarid region of Ceará, Brazil.

\section{MATERIAL AND METHODS}

The experiment was conducted from October 2010 to December 2011 at the Federal Institute of Ceará's (IFCE) Research and Extension's (UEPE) Unit of Teaching in Limoeiro do Norte-CE, Brazil $\left(05^{\circ} 10^{\prime} 38^{\prime \prime} \mathrm{S} ; 38^{\circ} 00^{\prime} 21^{\prime \prime} \mathrm{W} ; 144.6 \mathrm{~m}\right)$. The experiment included three cultivation environments: full sun (FS), trellis (TR), and greenhouse (GRH).

According to Köppen's climate classification, the experiment was located in a region with BSw'h' climate (i.e., semiarid hot), with the rainiest period from March to May and the driest period from July to December. In this region, the mean annual temperature is $28.5{ }^{\circ} \mathrm{C}$, the mean annual rainfall is $772 \mathrm{~mm}$, and the annual relative humidity is $62 \%$. Air temperature and relative humidity were measured for the three cultivation environment treatments and the monthly averages were used to calculate annual means (Table 1).

Table 1. Annual air temperature and relative humidity values obtained from monthly means measured in three cultivation environment treatments.

\begin{tabular}{ccccccc}
\hline \multirow{2}{*}{ Year } & \multicolumn{3}{c}{ Air temperature $\left({ }^{\circ} \mathrm{C}\right)$} & \multicolumn{3}{c}{ Relative humidity $(\%)$} \\
\cline { 2 - 7 } & Full sun & Trellis & Greenhouse & Full sun & Trellis & Greenhouse \\
\hline $2010^{\#}$ & 33.8 & 30 & 29.6 & 62 & 70 & 73 \\
$2011^{\# \#}$ & 32.4 & 30.5 & 29.1 & 66 & 69 & 71 \\
\hline
\end{tabular}

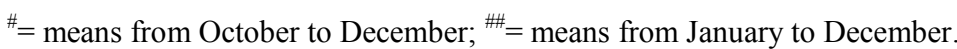

The soil used as our substrate was classified as Red Yellow Cambisol (Brazilian Soil Classification System (SiBCS); EMBRAPA, 2013), with a sandy clay loam texture, and a bulk density of $1.39 \mathrm{~g} \mathrm{~cm}^{-3}\left(0-20 \mathrm{~cm}\right.$ depth) and $1.3 \mathrm{~g} \mathrm{~cm}^{-3}(20-40$ $\mathrm{cm}$ depth). Individual samples were collected from the $0-20 \mathrm{~cm}$ and $20-40 \mathrm{~cm}$ depths in order to form composite samples for chemical characterization (based on methodologies suggested by the Brazilian Agricultural Research Corporation - EMBRAPA; (DONAGEMA et al., 2009), for the attributes shown in Table 2 . 
F. L. SILVA et al.

Table 2. Chemical characterization of the soil before application of treatments.

\begin{tabular}{|c|c|c|c|c|c|c|c|c|c|}
\hline Layers & $\mathrm{MO}$ & $\mathrm{P}$ & K & $\mathrm{Ca}$ & $\mathrm{Mg}$ & $\mathrm{pH}$ & $\mathrm{V}$ & ESP & ECes \\
\hline$(\mathrm{cm})$ & $\mathrm{g} \mathrm{Kg}^{-1}$ & $\mathrm{mg} \mathrm{dm}^{-3}$ & & $\mathrm{mmol}_{\mathrm{c}} \mathrm{dm}^{-3}$ & & $\mathrm{H}_{2} \mathrm{O}$ & & $\%$ & $\mathrm{dS} \mathrm{m} \mathrm{m}^{-1}$ \\
\hline $0-20$ & 23.84 & 57 & 9.32 & 122.5 & 29.0 & 6.0 & 84 & 2 & 1.0 \\
\hline $20-40$ & 10.13 & 19 & 8.78 & 135 & 49.5 & 6.3 & 90 & 9 & 0.24 \\
\hline
\end{tabular}

$\mathrm{MO}=$ organic matter; ECes= electrical conductivity of the extract soil; ESP= exchangeable sodium percentage; $\mathrm{V}=$ saturação por base.

The seedlings were transplanted to open holes $(40 \mathrm{~cm} \times 40 \mathrm{~cm} \times 40 \mathrm{~cm})$ at spacing of $1.5 \mathrm{~m} \times 1.5$ $\mathrm{m}$, corresponding to a planting density of 4444.44 plants $\mathrm{ha}^{-1}$. In October 2010, the holes were prepared with a basal fertilization of $20 \mathrm{~L}$ of weathered bovine manure $(\mathrm{C} / \mathrm{N}$ ratio of $28 / 1)$.

The crop was pruned three times during the experiment in order to be able to evaluate three production cycles. Since the chosen cultivar (Roxo de Valinhos) develops one fig per node at the insertion of each leaf on the branch, the number of fruits produced per plant would equal the number of nodes on the respective branches (CAETANO et al., 2005).

The formation pruning ( $1^{\circ}$ production cycle) was performed 60 days after transplantation (December 2010) at a height of $25 \mathrm{~cm}$ above the soil, which allowed the development of three branches. The second pruning ( $2^{\circ}$ production cycle) was performed 120 days after the formation pruning, and involved tipping (breaking the apical dominance) each of the three primary branches, resulting in six branches per plant. The third pruning $\left(3^{\circ}\right.$ production cycle) occurred 180 days after the formation pruning (June 2011), and involved tipping the branches that were developed in the second cycle, resulting in 12 branches per plant.

The experiment was a randomized complete block, split-split plot design, with four replicates, and three plants per plot. The plots corresponded to the three environments: full sun (FS), trellis (TR), and greenhouse (GRH). The subplots corresponded to the concentration of the bovine biofertilizer: T0 $(0 \%$ biofertilizer $+100 \%$ water $), \quad$ T1 $\quad(20 \%$ biofertilizer $+80 \%$ water $)$, T2 $(40 \%$ biofertilizer + $60 \%$ water), and T3 (60\% biofertilizer $+40 \%$ water). The sub-subplots corresponded to the production cycles: 1,2 , and 3 .

The first protected environment was a commercial greenhouse, with chapel-like architecture and the following dimensions: length of $32.0 \mathrm{~m}$, width of $6.4 \mathrm{~m}$, central height of $4.20 \mathrm{~m}$, and ceiling height of $3.0 \mathrm{~m}$. The wooden structure had an arched roof composed of galvanized iron, a $150-\mu \mathrm{m}$-thick low-density polyethylene (LDPE) cover with anti-UV filter, and laterals closed with a 3.0-mm-mesh screen.

The second environment was a modified open trellis, with support structures (columns and rafters) made from wood available in the region. The cover followed the same specifications as the greenhouse cover. The third environment was an open field. The last two environments had the same surface dimensions as the greenhouse (i.e., $32.0 \mathrm{~m} \times 6.4 \mathrm{~m}$ ).

The biofertilizer was prepared in a plastic biodigester where fresh bovine manure and water (50/50 split) fermented for 30 days under anaerobic conditions (PENTEADO, 2007). The mean chemical composition of the biofertilizer applied in the experiment is shown in Table 3.

Table 3. Chemical characteristics of biofertilizer after diluted with water in different concentrations.

\begin{tabular}{|c|c|c|c|c|c|c|c|c|c|c|c|}
\hline \multirow{3}{*}{ Samples } & \multicolumn{6}{|c|}{ Macronutrients } & \multicolumn{4}{|c|}{ Micronutrients } & Sodium \\
\hline & \multicolumn{6}{|c|}{$\mathrm{g} \mathrm{L}^{-1}$} & \multicolumn{5}{|c|}{$\mathrm{mg} \mathrm{L}^{-1}$} \\
\hline & $\mathrm{N}$ & $\mathrm{P}$ & K & $\mathrm{Ca}$ & $\mathrm{Mg}$ & $\mathrm{S}$ & $\mathrm{Fe}$ & $\mathrm{Zn}$ & $\mathrm{Cu}$ & $\mathrm{Mn}$ & $\mathrm{Na}$ \\
\hline $\mathrm{T} 1$ & 0.14 & 0.22 & 0.25 & 0.11 & 0.06 & 0.05 & 15.50 & 0.02 & 0.02 & 1.86 & 45.00 \\
\hline $\mathrm{T} 2$ & 0.23 & 0.23 & 0.49 & 0.24 & 0.11 & 0.08 & 30.10 & 0.80 & 0.02 & 3.40 & 52.00 \\
\hline $\mathrm{T} 3$ & 0.40 & 0.32 & 0.68 & 0.38 & 0.17 & 0.12 & 44.40 & 2.38 & 1.06 & 5.28 & 60.00 \\
\hline
\end{tabular}

The supply of the maximum dose of N, P, and K proposed by Tomé Júnior (1997) (Table 4) in the treatment with highest biofertilizer concentration $(60 \%)$ and the total supply of nutrients at the different concentrations applied (Table 5) were based on the chemical analyses of soil and biofertilizer. These calculations also considered soil bulk density 
$\left(1.4 \mathrm{~kg} \mathrm{dm}^{-3}\right)$ and a population of 4444.44 plants $\mathrm{ha}^{-1}$ at a spacing of $1.5 \mathrm{~m} \times 1.5 \mathrm{~m}$.

From October 2010 through December 2011 (15 months), the biofertilizer (at the T0, T1, T2, and
T3 concentrations) was applied biweekly at a volume of $3 \mathrm{~L}$ per plant, which meant a total of $90 \mathrm{~L}$ per plant applied over the three cycles.

Table 4. Amount of nutrients recommended for "Roxo de Valinhos" fig, in the soil and nutritional supplement needs.

\begin{tabular}{|c|c|c|c|}
\hline \multirow[t]{2}{*}{ Chemical characteristics } & \multicolumn{3}{|c|}{ Nutrient } \\
\hline & $\mathrm{N}$ & $\mathrm{P}_{2} \mathrm{O}_{5}$ & $\mathrm{~K}_{2} \mathrm{O}$ \\
\hline \multirow[t]{3}{*}{ Recommendation } & \multicolumn{3}{|c|}{$\left(\right.$ g plant $\left.^{-1}\right)$} \\
\hline & 36.6 & 9.0 & 2.2 \\
\hline & & $(\mathrm{g} \mathrm{kg}$ & \\
\hline \multirow[t]{3}{*}{ In the soil } & 0.024 & 0.057 & 0.0093 \\
\hline & \multicolumn{3}{|c|}{$\left(\right.$ g plant $\left.^{-1}\right)$} \\
\hline & 14.87 & 35.62 & 5.82 \\
\hline \multirow[t]{2}{*}{ Supplementary nutrition } & \multicolumn{3}{|c|}{$\left(\right.$ g plant $\left.^{-1}\right)$} \\
\hline & 21.73 & 54.38 & 16.18 \\
\hline
\end{tabular}

Table 5. Total supply of nutrients in the three cycles of "Roxo de Valinhos" fig.

\begin{tabular}{cccc}
\hline Treatment & \multicolumn{3}{c}{ Accumulation de nutrientes $^{*}$} \\
& $\mathrm{~N}$ & $\mathrm{P}_{2} \mathrm{O}_{5}$ & $\mathrm{~K}_{2} 0$ \\
\cline { 2 - 4 } & & $\mathrm{g} \mathrm{plant}^{-1}$ & \\
$\mathrm{~T}_{0}=00 \%\left(3 \mathrm{~L} \mathrm{fortnight}^{-1}\right.$ plant $\left.^{-1}\right)$ & 14.87 & 35.62 & 28.32 \\
$\mathrm{~T}_{1}=20 \%\left(3 \mathrm{~L} \mathrm{fortnight}^{-1}\right.$ plant $\left.^{-1}\right)$ & 29.27 & 49.12 & 49.92 \\
$\mathrm{~T}_{2}=40 \%\left(3 \mathrm{~L}\right.$ fortnight $^{-1}$ plant $\left.^{-1}\right)$ & 42.77 & 61.72 & 67.02 \\
$\mathrm{~T}_{3}=60 \%\left(3 \mathrm{~L} \mathrm{fortnight}^{-1}\right.$ plant $\left.^{-1}\right)$ & 57.17 & 75.22 & \\
\hline
\end{tabular}

* Sum of the amount present in the soil + amount applied by use of biofertilizers.

\section{RESULTS AND DISCUSSION}

Based on the analysis of variance, there were no significant cultivation environment $\times$ biofertilizer $x$ cycle interactions for any of the evaluated variables. However, there were significant cultivation environment $\times$ cycle interactions for mean mass of fruit (MMF), fruit diameter (FD), number of fruits per plant (NFP), and yield (Y), significant biofertilizer $\times$ cultivation environment interactions for MMF, FD, and NFP, and a significant cycle $\times$ biofertilizer interaction for Y (Table 6).

For MMF, there was no significant difference between the trellis treatment $(67.6 \mathrm{~g})$ and the greenhouse treatment $(66.4 \mathrm{~g})$, but both were significantly higher (Tukey's test: $\mathrm{P}<0.05$ ) than the full sun treatment $(58.2 \mathrm{~g})$. In the second and third cycles, MMF values for the trellis treatment (64.6 and $61.1 \mathrm{~g}$, respectively) were significantly higher ( $\mathrm{P}$ $\leq 0.05)$ than the values for the other treatments (Table 7).

The higher MMF values for the TR and GRH treatments, compared to the FS treatment, can be explained by the variation in the evapotranspiration in these environments. The result of the GRH treatment is consistent with the claim of Sousa Neto et al. (2010). These authors reported that thermo-reflective screens under the polyethylene film allow better use of solar radiation, temperature, and relative humidity, promoting better physical-climatic conditions for crop development, in addition to the benefits provided by the cover (REIS et al., 2012). On the other hand, in the FS treatment, the crop is continually exposed to variable conditions (e.g., temperature and relative humidity), which leads to undesirable consequences for commercial cultivation (SOUZA et al., 2009). 
Table 6. Summary of the analysis of variance for the average fruit mass (MMF), fruit diameter (DF), number of fruits per plant (NFP) and productivity (PROD) under different cultivation environments, biofertilizers concentrations and culture of the crop cycle of "Roxo de Valinhos" fig.

\begin{tabular}{|c|c|c|c|c|c|}
\hline \multirow{2}{*}{$\mathrm{FV}$} & \multirow{2}{*}{ GL } & \multicolumn{4}{|c|}{ Mean Squares } \\
\hline & & $\operatorname{MMF}(\mathrm{g})$ & $\mathrm{DF}(\mathrm{cm})$ & NFP (un) & $\operatorname{PROD}\left(\mathrm{t} \mathrm{ha}^{-1}\right)$ \\
\hline Blocks & 3 & 194.06601 & 23.3709 & 50.97454 & 0.46811 \\
\hline Environmental (A) & 2 & $2636.915^{* *}$ & $467.0376^{* *}$ & $282.5122^{\mathrm{ns}}$ & $28.16981^{\mathrm{ns}}$ \\
\hline Resídue (A) & 6 & 74.92109 & 20.3449 & 17.00752 & 1.959885 \\
\hline CB (B) & 3 & $1283.302^{* *}$ & $51.69390^{\mathrm{ns}}$ & $1650.990^{* *}$ & $129.4521^{\mathrm{ns}}$ \\
\hline Interaction $(\mathrm{A} \times \mathrm{B})$ & 6 & $24.05094^{\mathrm{ns}}$ & $12.04787^{\mathrm{ns}}$ & $13.46557^{\mathrm{ns}}$ & $0.92487^{\mathrm{ns}}$ \\
\hline Resídue (B) & 27 & 22.64156 & 5.62047 & 12.57861 & 0.682214 \\
\hline Cycle (C) & 2 & $2094.705^{* *}$ & $881.3099^{\mathrm{ns}}$ & $5413.752^{\mathrm{ns}}$ & $452.3051^{\mathrm{ns}}$ \\
\hline Interaction $(\mathrm{A} \times \mathrm{C})$ & 4 & $221.8703^{* *}$ & $365.8994^{* *}$ & $124.4392^{* *}$ & $8.348520^{* *}$ \\
\hline Interaction $(\mathrm{B} \times \mathrm{C})$ & 6 & $46.50908^{\mathrm{ns}}$ & $60.71302^{\mathrm{ns}}$ & $95.41869^{\mathrm{ns}}$ & $8.316000^{* *}$ \\
\hline Interaction $(\mathrm{A} \times \mathrm{B} \times \mathrm{C})$ & 12 & $30.91898^{\mathrm{ns}}$ & $12.91432^{\text {ns }}$ & $11.25643^{\text {ns }}$ & $0.306256^{\mathrm{ns}}$ \\
\hline Resídue (C) & 72 & 38.9007 & 11.84704 & 10.0047 & 0.917882 \\
\hline VC (A) & - & 10.82 & 6.43 & 9.49 & 14.72 \\
\hline VC (B) & - & 12.6 & 9.81 & 10.34 & 14.56 \\
\hline $\mathrm{VC}(\mathrm{C})$ & - & 13.4 & 10.12 & 12.11 & 13.56 \\
\hline
\end{tabular}

Source of variation; Freedom degree; concentrations of biofertilizer; $\mathrm{VC}=$ variation coeficiente; $\mathrm{ns}=\mathrm{Not}$ significant; $* * *$ $=$ significant at 5 and $1 \%$ level by the test $\mathrm{F}$.

Table 7. Mean mass of fruit values for "Roxo de Valinhos" fig in different environment and production cycle treatments.

\begin{tabular}{cccc}
\hline \multirow{2}{*}{ Cycle } & & Cultivation environment & \\
\cline { 2 - 4 } & Full sun & Trellis & Greenhouse \\
\hline 1 & $58.2 \mathrm{Ba}$ & $67.6 \mathrm{Ab}$ & $66.4 \mathrm{Aa}$ \\
2 & $46.2 \mathrm{Bb}$ & $64.6 \mathrm{Ab}$ & $55.3 \mathrm{Bb}$ \\
3 & $41.9 \mathrm{Bb}$ & $61.1 \mathrm{Ab}$ & $54.4 \mathrm{Bb}$ \\
\hline
\end{tabular}

Means followed by different letters, lowercase (a, b) in columns and uppercase (A, B) in rows, significantly differ (Tukey's test: $\mathrm{P} \leq 0.05)$.

In the third cycle, MMF values were similar to those obtained by Nienow et al. (2006), who worked with a fig crop in a protected environment. For these authors, in their second cycle, plants produced heavier fruits $(57.5 \mathrm{~g})$ and, in their third cycle, the values (50.3 and $52.4 \mathrm{~g}$ ) were between the lowest and the highest mean mass of fruits.

Regardless of the type of cultivation, bovine biofertilizer had a positive relationship with MMF, with each increase in biofertilizer concentration corresponding to an increase in weight: $0.2696 \mathrm{~g}$ (first cycle), $0.1883 \mathrm{~g}$ (second cycle), and $0.2328 \mathrm{~g}$ (third cycle) (Figure 1). For the three cycles, the MMF ranged from 56.99 to $77.16 \mathrm{~g}$ (first cycle), 49.70 to $61.00 \mathrm{~g}$ (second cycle), and 45.54 to 59.51 $\mathrm{g}$ (third cycle). When comparing the T0 and T4 treatments, these values corresponded to $\mathrm{MMF}$ differences of $35.39,22.73$, and $30.67 \%$ for each of the cycles, respectively. However, in the third cycle, there was an increment in the mean value of fruit mass $(15 \mathrm{~g})$, which ranged from 45 to $60 \mathrm{~g}$. It should be pointed out that the nutritional increment from the biofertilizer favors a higher gain of fruit mass (RODRIGUES et al., 2008; SANTOS et al., 2012). 


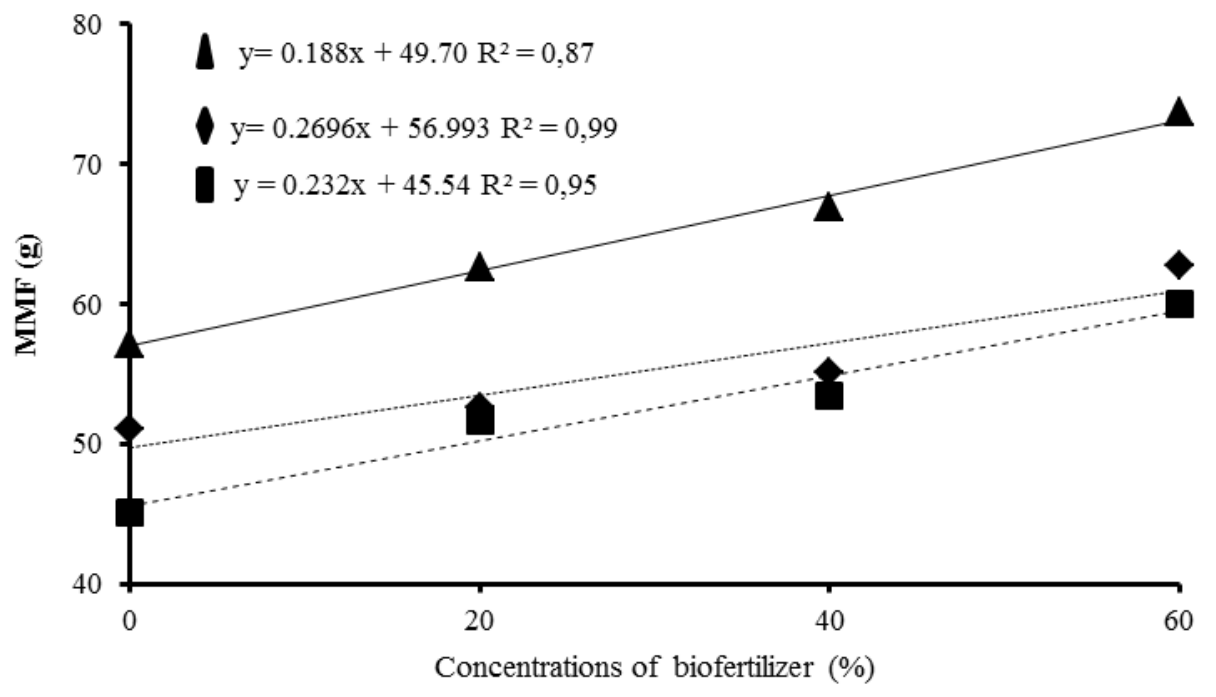

Figure 1. Fruit mass by "Roxo de Valinhos" fig according to the biofertilizer concentrations applied to the soil during the first $(\boldsymbol{\Lambda})$, second $(\diamond)$ and third cycle $(\boldsymbol{\square})$.

Positive effects of biofertilizer applications have been reported for other crops, such as yellow passion fruit (MESQUITA et al., 2007) and yam tubers (SILVA et al. 2012). In contrast, applying a liquid organic compound $\left(30,60\right.$ and $90 \mathrm{~L} \mathrm{ha}^{-1}$ year $^{-1}$ under full sun conditions) to a melon crop did not elicit a positive response (FREIRE et al., 2009).

There was a significant interaction of cultivation environment $\times$ cycle for fruit diameter
(Table 8). In the first cycle, the highest fruit diameter was in the GRH treatment $(66.4 \mathrm{~mm})$ (Tukey's test: $\mathrm{P}<0.05)$, compared to the FS treatment $(53.0 \mathrm{~mm})$ and the TR treatment $(55.2 \mathrm{~mm})$. On the other hand, for the second and third cycles, the mean values in the TR (55.8 and $53.2 \mathrm{~mm}$ ) and GRH (56.5 and 58.5 $\mathrm{mm}$ ) treatments were significantly higher than in the FS treatment (51.2 and $45.7 \mathrm{~mm}$ ).

Table 8. Mean values of fruit diameter for "Roxo de Valinhos" fig in different environment and production cycle treatments

\begin{tabular}{cccc}
\hline \multirow{2}{*}{ Cycle } & \multicolumn{3}{c}{ Cultivation environment } \\
\cline { 2 - 4 } & Full sun & Trellis & Greenhouse \\
\hline 1 & $53.0 \mathrm{Ba}$ & $55.2 \mathrm{Ba}$ & $66.4 \mathrm{Aa}$ \\
2 & $51.2 \mathrm{Ba}$ & $55.8 \mathrm{Aa}$ & $56.5 \mathrm{Ab}$ \\
3 & $45.7 \mathrm{Bb}$ & $53.2 \mathrm{Aa}$ & $58.5 \mathrm{Ab}$ \\
\hline
\end{tabular}

Means followed by different letters, lowercase $(a, b)$ in columns and uppercase $(A, B)$ in rows, significantly differ (Tukey's test: $\mathrm{P} \leq 0.05$ ).

According to Santos et al. (2011), fig fruits, based on their diameter, are classified as extra large ( $\geq 65 \mathrm{~cm}$ ), large (55 to $64 \mathrm{~cm}$ ), medium (45 and 54 $\mathrm{cm})$, small (32 and $44 \mathrm{~cm})$, and very small $(\leq 31$ $\mathrm{cm})$. The first cycle contained the largest fruits, which was due to the higher concentration of nutrients in the productive branches (i.e., greater translocation of $\mathrm{N}, \mathrm{P}$, and $\mathrm{K}$ between the source (leaf) and the sink (fruit)).

Our results were similar to those reported by Rodrigues et al. (2009), who observed that the "Supermagro" biofertilizer resulted in an increase in the longitudinal and transverse diameter of yellow passion fruits. Similarly, Santos et al. (2014) observed a positive effect of mixed biofertilizer on the transverse diameter of melon fruits.

There was a significant interaction of cultivation environment $\times$ cycle for number of fruits per plant (Table 9). In the first cycle, there were no significant differences between the mean values $(47$, 46 , and 44 fruits per plant). In the second cycle, there was significantly (Tukey's test: $\mathrm{P} \leq 0.05$ ) more fruit in the full sun treatment (31 fruits per plant) than in the trellis (27 fruits per plant) and greenhouse (21 fruits per plant) treatments. In the third cycle, the trellis treatment had significantly $(\mathrm{P} \leq 0.05)$ more fruit ( 31 fruits per plant) than the full sun $(27$ fruits per plant) and greenhouse treatments (26 fruits per plant). 
Table 9. Mean values of number of fruits per plant for "Roxo de Valinhos" fig in different environment and production cycle treatments.

\begin{tabular}{cccc}
\hline \multirow{2}{*}{ Cycle } & & Cultivation environment & \\
\cline { 2 - 4 } & Full sun & Trellis & Greenhouse \\
\hline 1 & $47 \mathrm{Aa}$ & $46 \mathrm{Aa}$ & $44 \mathrm{Aa}$ \\
2 & $31 \mathrm{Ab}$ & $27 \mathrm{Bc}$ & $21 \mathrm{Bb}$ \\
3 & $27 \mathrm{Bb}$ & $31 \mathrm{Ab}$ & $26 \mathrm{Bb}$ \\
\hline
\end{tabular}

Means followed by different letters, lowercase $(a, b)$ in columns and uppercase $(A, B)$ in rows, significantly differ (Tukey's test: $\mathrm{P} \leq 0.05$ ).

The variation in fruit numbers between the second and third cycles is directly related to the solar radiation imposed on the crop during the experiment. Lacerda et al. (2010) reported that using screens that only allowed $50 \%$ passage of solar radiation caused different reactions in crops. These authors also suggested that $\mathrm{C}_{3}$ plants showed lower growth performance than $\mathrm{C}_{4}$ plants when cultivated under full sun and protected environments.

Regarding the number of fruits per plant (Figure 2), although there was a positive relationship between bovine biofertilizer and fruit number, there was still an overall reduction in fruit from one cycle to the next. Caetano et al. (2005) warned that a decrease in the number of reproductive buds (i.e., undifferentiated buds) from one cycle to the next would cause a reduction in fruit number. Caetano and Carvalho (2006) observed that in the third cycle, fig plants with only 16 to 32 branches had a reduced number of fruits per branch.

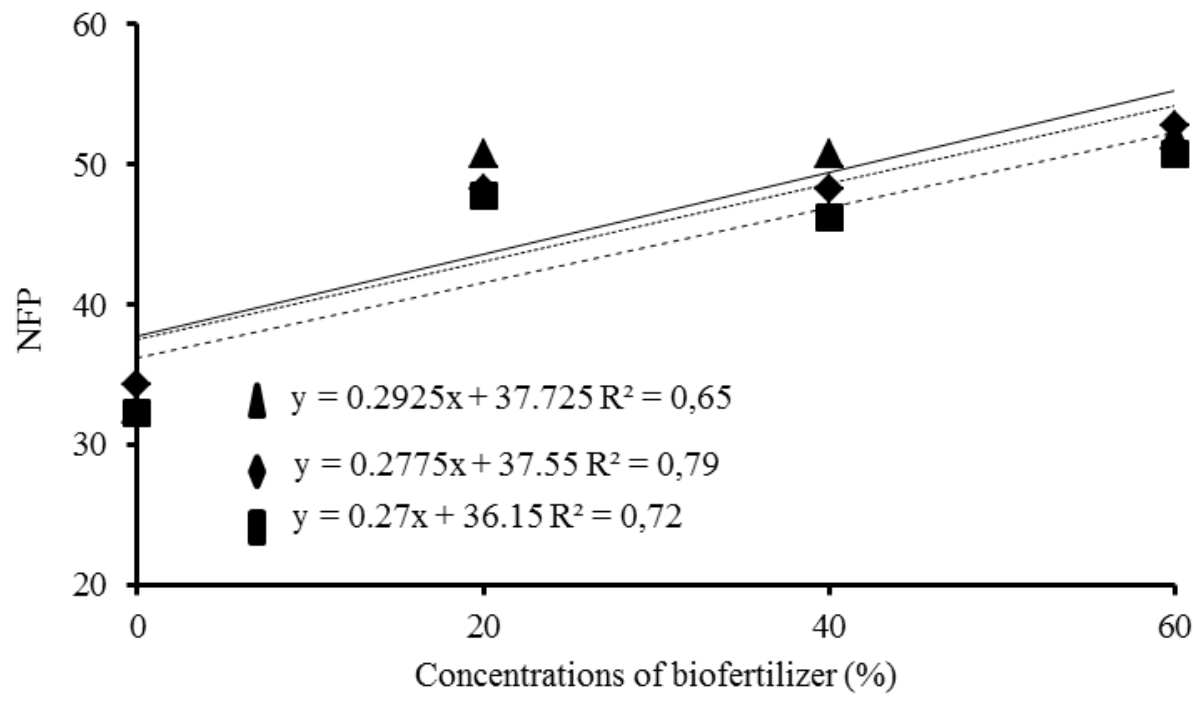

Figure 2. Number of fruits per plant by "Roxo de Valinhos" fig according to the biofertilizer concentrations applied to the soil during the first $(\boldsymbol{\Delta})$, second $(\boldsymbol{})$ and third cycle $(\boldsymbol{\square})$.

As shown in Table 10, there was a significant interaction of cycle $\times$ cultivation environment for fig yield. In the first cycle, the TR and GRH treatments had significantly higher yields (10.44 and $9.92 \mathrm{t} \mathrm{ha}^{-1}$, respectively) than the FS treatment $\left(8.62 \mathrm{t} \mathrm{ha}^{-1}\right)$. In the second cycle, there were no significant differences among cultivation environments. However, in the third cycle, the TR treatment had significantly higher yield $\left(6.47 \mathrm{t} \mathrm{ha}^{-1}\right)$ than the GRH $\left(4.37 \mathrm{t} \mathrm{ha}^{-1}\right)$ and FS $\left(3.81 \mathrm{tha}^{-1}\right)$ treatments. 
Table 10. Mean values of significant interactions for the yield of 'Roxo de Valinhos' fig in different environments and production cycles.

\begin{tabular}{cccc}
\hline \multirow{2}{*}{ Cycle } & \multicolumn{3}{c}{ Cultivation environments } \\
\cline { 2 - 4 } & Full sun & Trellis & Greenhouse \\
\hline 1 & $8.62 \mathrm{Ba}$ & $10.44 \mathrm{Aa}$ & $9.92 \mathrm{Aa}$ \\
2 & $4.83 \mathrm{Ab}$ & $5.65 \mathrm{Ab}$ & $4.12 \mathrm{Ab}$ \\
3 & $3.81 \mathrm{Bb}$ & $6.47 \mathrm{Ab}$ & $4.37 \mathrm{Bb}$ \\
\hline
\end{tabular}

Means followed by different letters, lowercase $(\mathrm{a}, \mathrm{b})$ in columns and uppercase $(\mathrm{A}, \mathrm{B})$ in rows, significantly differ (Tukey's test: $\mathrm{P} \leq 0.05$ ).

According to Caetano et al. (2005), shading compromised the emergence of reproductive buds and, consequently, the yield, and this could partly explain the reason for the lower yields in the second and third cycles. Additionally, the plants had less time to recover after the second and third pruning (i.e., shorter intervals) than after the first pruning, and would have required a greater supply of nutrients to produce high yields.

For the three production cycles, the relationship between bovine biofertilizer concentrations and fig yield can be observed in
Figure 3 . In the first cycle, the mean yield obtained at the highest concentration $(60 \%)$ was $10.35 \mathrm{t} \mathrm{ha}^{-1}$. The mean yields were lower in the second $\left(7.32 \mathrm{t} \mathrm{ha}^{-1}\right)$ and third $\left(6.98 \mathrm{tha}^{-1}\right)$ cycles.

It is important to note that the bovine biofertilizer helps release humic substances in the soil that improve soil structure and increase soil microbial populations, thereby increasing the solubility and availability of some soil nutrients (e.g., phosphorus), which, in turn, would increase crop yield (SANTOS et al., 2014).

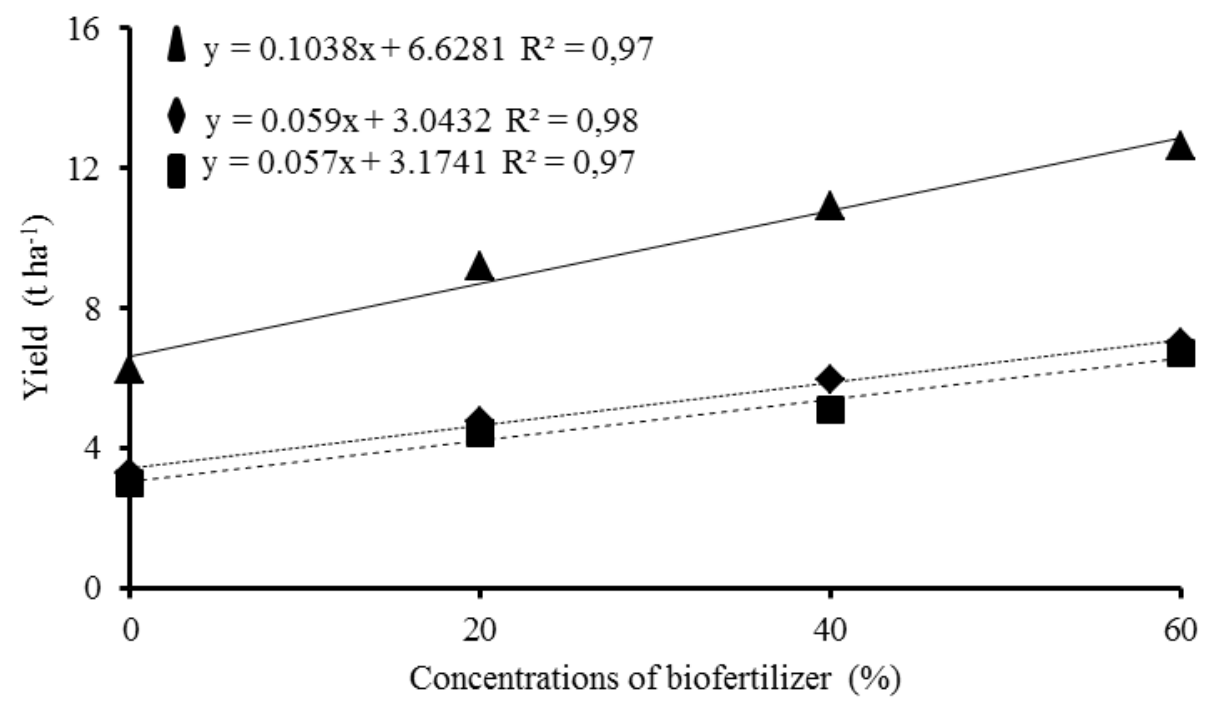

Figure 3. Yield per plant by "Roxo de Valinhos" fig according to the biofertilizer concentrations applied to the soil during the first $(\mathbf{\Delta})$, second $(\boldsymbol{\nabla})$ and third cycle $(\boldsymbol{\square})$.

In our study, the mean yield was lower than the national mean yield $\left(8.2 \mathrm{t} \mathrm{ha}^{-1}\right.$; SOUZA et al., 2009); however, we had promising results for the use of liquid organic fertilizer in fig production, which were similar to results reported by Diniz et al. (2011) for yellow passion fruit (Passiflora edulis). These authors point out that the application of organic fertilizers in a liquid form, such as bovine biofertilizer, promotes greater transport of necessary nutrients to the plants. Similar studies have also shown the benefit of organic fertilizers (e.g., bovine and poultry manure) on the yield of fig and guarana trees (LEONEL; DAMATTO JÚNIOR, 2008; ARRUDA et al. 2010).

\section{CONCLUSIONS}

The cultivation environments (greenhouse and trellis) promote better performance in mean mass and diameter of fruits compared with plants grown under full sun during the production cycles of the fig crop cultivated in the semiarid region of Ceará.

Bovine biofertilizer at the concentration of $60 \%$ promoted greater mass, diameter, number of fruits per plant and yield in the fig crop. 


\section{REFERENCES}

ARRUDA, M. R. et al. Produtividade, fertilidade do solo e estado nutricional de clones de guaranazeiro cultivados com fontes orgânicas de nutrientes. Revista Amazonian Jornal, Belém, v. 55, n. 4, p. 311-317, 2012.

CAETANO, L. C. S.et al. Efeito do número de ramos produtivos sobre o desenvolvimento da área foliar e produtividade da figueira. Revista Brasileira de Fruticultura, Jaboticabal, v. 27, n. 3, p. 426-429, 2005.

CAETANO, L. C. S.; CARVALHO, A. J. C. Efeito da adubação com boro e esterco bovino sobre a produtividade da figueira e as propriedades químicas do solo. Ciência Rural, Santa Maria, v. 36, n. 4, p. 1150-1155, 2006

CAVALCANTE, L. F. et al. Crescimento e produção do maracujazeiro-amarelo em solo de baixa fertilidade tratado com biofertilizantes líquidos. Revista Brasileira de Ciências Agrárias, Recife, v. 2, n. 3, p.15-19, 2007.

COSTA, E. et al. Efeitos do organosuper ${ }^{\circledR}$ e do ambiente protegido na formação de mudas de mamoeiro. Revista Engenharia Agrícola, Jaboticabal, v. 31, n. 1, p. 41-55, 2011.

DINIZ, A. A. et al. Esterco líquido bovino e ureia no crescimento e produção de biomassa do maracujazeiro amarelo. Revista Ciência Agronômica, Fortaleza, v. 42, n. 3, p. 597-604, 2011.

DONAGEMA, G. K. et al. Manual de métodos de análise de solos. 2. ed. Rio de Janeiro, RJ: EMBRAPA SOLOS, 2011. 230 p.

FREIRE G. M. et al. Aplicação de composto orgânico líquido via fertirrigação na cultura do meloeiro. Bioscience Journal, Uberlândia, v. 25, n. 5, p. 49-55, 2009.

INSTITUTO BRASILEIRO DE GEOGRAFIA E ESTATÍSTICA (IBGE). Disponível em: $<$ http:// www.sidra.ibge.gov.br/bda/agric/>. Acessado em: 15 jan. 2016

LACERDA, C. F. et al. Análise de crescimento de milho e feijão sob diferentes condições de sombreamento. Revista Brasileira de Ciência Agrárias, Recife, v. 5, n. 1, p. 18-24, 2010.

LEONEL, S.; DAMATTO JUNIOR, E. R. Efeitos do esterco de curral na fertilidade do solo, no estado nutricional e na produção da figueira. Revista Brasileira de Fruticultura, Jaboticabal, v. 30, n. 2, p. 534-539, 2008.

MESQUITA, E. F. et al. Produtividade e qualidade de frutos do mamoeiro em função de tipos e doses de biofertilizantes. Semina, Londrina, v. 28, n. 4, p. 589 $-596,2007$.

NIENOW, A. A. et al. Produção da figueira em ambiente protegido submetida a diferentes épocas de poda e número de ramos. RevistaBrasileira de Fruticultura, Jaboticabal, v. 25, n. 3, p. 421-424, 2006

PENTEADO, S.R. Adubação Orgânica: Compostos orgânicos e biofertilizantes. 2. ed. Campinas, SP: Edição do autor, 2007.162 p.

REIS, L. S. et al. Componentes da radiação solar em cultivo de tomate sob condições de ambiente protegido. Revista Brasileira de Engenharia Agrícola e Ambiental, Campina Grande, v. 16, n. 7, p. 739-744, 2012.

REIS et al. Índice de área foliar e produtividade do tomate sob condições de ambiente protegido.Revista Brasileira de Engenharia Agrícola e Ambiental, Campina Grande, v. 17, n. 4, p. 386-391, 2013.

RIBEIRO JÚNIOR, J. I. Análises estatísticas no SAEG. 1. ed. Viçosa, MG: UFV, 2001. 301 p.

RODRIGUES, A. C. et al. Caracterização de frutos de maracujazeiro amarelo em solo tratado com biofertilizante supermagro. Magistra, Cruz das Almas, v. 20, n. 3, p. 264-272, 2008.

RODRIGUES, A. C. et al. Biofertilizante supermagro e potássio na fertilidade de um solo cultivado com maracujazeiro amarelo. Revista Verde deAgroecologia e Desenvolvimento Sustentável, Mossoró, v. 4, n. 1, p. 76-84, 2009.

SALES et al. Telas agrícolas como subcobertura no cultivo de alface hidropônica. Ciência Rural, Santa Maria, v. 44, n. 10, p. 1755-1760, 2014

SANTOS F. V. L. F. et al. Evolução e aspectos socioeconômicos da cultura do figo no estado de São Paulo. Informações econômicas, São Paulo, v. 41, n. 2, p. 13-22, 2011.

SANTOSM. R. et al. Rendimento, qualidade absorção de nutrientes pelos frutos de abóbora em função de doses de biofertilizante. Horticultura Brasileira, Brasília, v. 30, n. 1, p. 160-167. 2012.

SANTOS, H. G. Sistema brasileiro de classificação 
de solos. 3. ed. Rio de Janeiro, RJ: Centro Nacional de Pesquisa de Solos; 2013. 353 p.

SANTOS, A. P. G. et al. Produtividade e qualidade de frutos do meloeiro em função de tipos e doses de biofertilizantes. Horticultura Brasileira, Brasília, v. 32, n. 4, p. 409-416, 2014.

SILVA, J. C. P. M. et al. Esterco líquido de bovinos leiteiros combinado com adubação mineral sobre atributos químicos de um Latossolo Bruno. Revista Brasileira de Ciência do Solo, Viçosa, v. 32, n. 6, p. 2563-2572, 2008.

SILVA, A. C. et al. Trocas gasosas e ciclo fotossintético da figueira 'Roxo de Valinhos.Ciência Rural, Santa Maria, v. 40, n. 1, p. 1270-1276, 2010.

SILVA, J. A. et al. Rendimento do inhame adubado com esterco bovino e biofertilizante no solo e na folha. Revista Brasileira de Engenharia Agrícola e Ambiental, Campina Grande, v. 16, n. 3, p. 253-257, 2012.

SOUSA NETO, O. N. et al. Produção de alface hidropônica e microclima de ambiente protegido sob malhas termo-refletoras. Revista Caatinga, Mosorró, v. 23, n. 4, p. 84-90, 2010.

SOUSA, G. G. et al. Fertirrigação com biofertilizante bovino: efeitos no crescimento, trocas gasosas e na produtividade do pinhão-manso. Revista Brasileira de Ciências Agrárias, Recife, v. 8, n. 3, p. 503-509, 2013.

SOUZA, A. P. et al. Temperaturas basais e soma térmica para a figueira podada em diferentes épocas. Revista Brasileira de Fruticultura, Jaboticabal, v. 31, n. 2, p. 314-322, 2009.

SOUZA, O. P.; MELO, B.; MANCIN, C. A. Cultura da Figueira. Disponível em: $<$ http:// www.fruticultura.iciag.ufu.br/figo.>. Acesso em: 05 fev. 2016.

TOMÉ JUNIOR, J. B. Manual para interpretação de análise de solo. 1 ed. Guaíba, RS: Agropecuária, 1997. $247 \mathrm{p}$.

VIANA, T. V. A. et al. Trocas gasosas e teores foliares de NPK em meloeiro adubado com biofertilizantes. Revista Brasileira de Ciências Agrárias, Recife, v. 8, n. 4, p. 595-601, 2013. 